\title{
The regulation of poly- $\beta$-hydroxybutyrate metabolism in Azospirillum brasilense during balanced growth and starvation
}

\author{
Sara Tal, ${ }^{1} \dagger$ Patricia SmirnofF ${ }^{2}$ and YaAcov OKON ${ }^{1 *}$ \\ ${ }^{1}$ Department of Plant Pathology and Microbiology, and ${ }^{2}$ Department of Biochemistry and Human Nutrition, Faculty of \\ Agriculture, The Hebrew University of Jerusalem, Rehovot 76100, Israel
}

(Received 29 September 1989; revised 16 March 1990; accepted 6 April 1990)

\begin{abstract}
Activities of the enzymes which are involved in the poly- $\beta$-hydroxybutyrate (PHB) cycle, in both synthesis and degradation reactions, were assayed in crude extracts of $A$ Azospirillum brasilense cells containing different amounts of PHB. The enzymes of the PHB cycle, of both the synthesis and the degradation process, were more active in PHB-rich cells than in PHB-poor cells. During $96 \mathrm{~h}$ of starvation of cells suspended in phosphate buffer, enzymes of the PHB cycle were more active in PHB-rich cells. There was a peak of activity of hydroxybutyrate dehydrogenase (BOHB-DH), $\beta$-ketothiolase and thiophorase after $24 \mathrm{~h}$ of starvation, due to polymer degradation. During the following hours of starvation there was a decrease in the activity of these enzymes. After $24 \mathrm{~h}$ of starvation the activity of acetoacetyl-CoA reductase dropped to a minimum level, because the cells could not synthesize PHB under these conditions. The specific activities of BOHB-DH, $\beta$-ketothiolase and thiophorase were higher in $A$. brasilense cells which were grown under low oxygen tension and consequently accumulated high levels of PHB, than in cells grown under high oxygen tension, with a low PHB content. Similarities to the pathway of PHB biosynthesis and degradation and its control in Azotobacter beijerinckii are described.
\end{abstract}

\section{Introduction}

Poly- $\beta$-hydroxybutyrate (PHB) is synthesized and accumulated by Azospirillum brasilense Cd up to $70 \%$ of the cell dry weight. PHB synthesis is favoured under oxygen limitation and by a high $\mathrm{C} / \mathrm{N}$ ratio towards the end of exponential growth in batch culture (Tal \& Okon, 1985).

A cyclic mechanism for the biosynthesis and degradation of PHB in Azotobacter beijerinckii was proposed by Senior \& Dawes (1973). They also proposed a regulatory scheme for the PHB cycle. Certain similarities were found in the cyclic pathway and its control between Azotobacter beijerinckii and Hydrogenomonas eutropha (Oeding \& Schlegel, 1973). These two groups suggested that the PHB cycle is controlled by the redox state of the cell and by the concentration of CoA-SH, pyruvate and 2-oxoglutarate. Our work with Azospirillum brasilense (Tal et al., 1990) suggested a similar control mechanism in this organism.

Azospirillum brasilense is a rhizosphere microorganism with potential use as an inoculant for promot-

† Present address: Department of Molecular Biology and Biochemistry, University of California, Irvine, Irvine, CA 92717, USA.

Abbreviations: BOHB-DH, D(-)-3-hydroxybutyrate dehydrogenase; CoA-SH, coenzyme A; PHB, poly- $\beta$-hydroxybutyrate. ing crop plant growth (Okon, 1985a, b). Tal \& Okon (1985) showed that in the presence of stress factors, PHBrich $A$. brasilense survived better than PHB-poor cells. This ability to survive adverse conditions is important in the rhizosphere. PHB degradation and its utilization as sole carbon and energy source by $A$. brasilense could be involved in favouring establishment, proliferation, survival and competition with other micro-organisms in the rhizosphere (Tal \& Okon, 1985). It is therefore, important to study and examine in detail the PHB cycle in $A$. brasilense. This paper reports studies of the enzymes and intermediates which are involved in the cycle, and the mechanism of the regulation of synthesis and degradation of the polymer.

\section{Methods}

Chemicals. The following were obtained from Sigma: disodium succinate, DTT, $\mathrm{Na}_{2}$ EDTA, NAD ${ }^{+}, \mathrm{NADP}^{+}, \mathrm{NADH}, \mathrm{NADPH}$, $\mathrm{CoASH}$, acetyl-CoA, hydroxybutyryl-CoA, 3-hydroxybutyrate sodium salt, hydroxybutyryl-CoA dehydrogenase, aceto setic acid and malic acid.

Bacterial strain and growth conditions. Azospirillum brasilense $\mathrm{Cd}$ (ATCC 29729) was used throughout. The following growth conditions were used. 
(a) Cells were grown in batch culture $\left(120\right.$ r.p.m.) at $32^{\circ} \mathrm{C}$ for $36 \mathrm{~h}$, in ammonia-malate mineral medium (Okon et al., 1976) which, unless stated otherwise, contained $2.8 \mathrm{mM}-\mathrm{NH}_{4} \mathrm{Cl}$. The concentration of carbon source (malic acid) was $45 \mathrm{~mm}$. The $\mathrm{C} / \mathrm{N}$ ratio was therefore 46 . Towards the end of the exponential growth stage $(36 \mathrm{~h})$, the cells were harvested and crude extract was prepared as described below. PHB accumulation is favoured under these conditions and its content in the cell is around $40 \%$ of the dry weight.

(b) Cells were grown as described in (a), except that $\mathrm{NH}_{4} \mathrm{Cl}$ concentration in the medium was $14.8 \mathrm{~mm}(\mathrm{C} / \mathrm{N}=8.7)$. The cells, in which PHB comprised around $5 \%$ of the dry weight, were collected after $36 \mathrm{~h}$ of growth and crude extract was prepared.

(c) Cells were grown as described in (a) $(\mathrm{C} / \mathrm{N}=46)$. After $36 \mathrm{~h}$ of growth the cells were harvested, using sterile techniques, centrifuged at $5000 \mathrm{~g}$ for $10 \mathrm{~min}$ and washed twice with sterile $0.06 \mathrm{M}$-potassium phosphate buffer, $\mathrm{pH} \mathrm{6.8.} \mathrm{After} \mathrm{washing,} \mathrm{the} \mathrm{cells} \mathrm{were} \mathrm{resuspended} \mathrm{in}$ the same buffer up to the initial volume, and were maintained under these starvation conditions for an additional $96 \mathrm{~h}$. During this period samples were taken every $24 \mathrm{~h}$, and crude extracts were prepared.

(d) Cells were grown as described in $(b)(\mathrm{C} / \mathrm{N}=8.7)$ and were starved as described in $(c)$. Crude extracts were prepared.

Crude extract preparation. Cultures of each treatment above were collected by centrifugation at $5000 \mathrm{~g}$ for $10 \mathrm{~min}$ and washed twice with the appropriate buffer, depending upon the enzyme of interest. The cells were then resuspended in approximately 5 vols of the particular buffer. All subsequent procedures were carried out at $4{ }^{\circ} \mathrm{C}$. The bacterial suspension was disintegrated in a French pressure cell at 30000 p.s.i. (207 MPa). Crude extract was prepared by centrifuging the disintegrated cell suspension at $35000 \mathrm{~g}$ for $20 \mathrm{~min}$; the supernatant was decanted and used for enzyme assays.

Activity assays of $\mathrm{PHB}$ cycle enzymes in crude extracts. Hydroxybutyrate dehydrogenase (BOHB-DH) (EC 1.1.1.30). The assays of Senior \& Dawes (1973) and Tal et al. (1990) were used, with minor modifications in the concentration of the reactants. Activity was measured in both the oxidation direction [D(-)-3-hydroxybutyrate + $\mathrm{NAD}^{+} \rightarrow$ acetoacetate $+\mathrm{NADH}$ ] and the reduction direction [acetoacetate $+\mathrm{NADH} \rightarrow \mathrm{D}(-)$-3-hydroxybutyrate $\left.+\mathrm{NAD}^{+}\right]$, by following the change in absorbance at $340 \mathrm{~nm}$ at $36^{\circ} \mathrm{C}$. One unit of enzyme activity was defined as $1 \mu \mathrm{mol} \mathrm{NAD}^{+}$reduced or $\mathrm{NADH}$ oxidized $\min ^{-1}\left(\varepsilon\right.$ for $\left.\mathrm{NADH}=6.21 \times 10^{3} \mathrm{M}^{-1} \mathrm{~cm}^{-1}\right)$.

$\beta$-Ketothiolase (acetyl-CoA acetyltransferase) (EC 2.3.1:9). The assays of Senior \& Dawes (1973), Oeding \& Schlegel (1973) and Ruhr \& Schlegel (1975) were used. The activity for the condensation reaction [2 acetyl-CoA $\rightarrow$ acetoacetyl-CoA $+\mathrm{CoA}-\mathrm{SH}]$ was calculated as described above for BOHB-DH. The activity for the catalytic cleavage reaction [acetoacetyl- $\mathrm{CoA}+\mathrm{CoA}-\mathrm{SH} \rightarrow 2$ acetyl-CoA] was measured at $303 \mathrm{~nm}$. The decrease in $A_{303}$ measures the decrease in the $\mathrm{Mg}^{2+}$ enol complex of acetoacetyl-CoA. One unit was defined as the decrease in $A_{303} \mathrm{~min}^{-1}$.

Thiophorase (succinyl-CoA CoA transferase EC 2.8.3.5). The assays of Senior \& Dawes (1973), Oeding \& Schlegel (1973) and Ruhr \& Schlegel (1975) were used. The activity for the reaction [acetoacetyl$\mathrm{CoA}+$ succinate $\rightarrow$ acetoacetate + succinyl-CoA] was measured spectrophotometrically, at $303 \mathrm{~nm}$, as in the cleavage reaction by $\beta$ ketothiolase.

Acetoacetyl-CoA reductase (D- $\beta$-hydroxybutyryl-CoA : NADH oxidoreductase) (EC 1.1.1.36). The assays of Senior \& Dawes (1973) and Ritchie et al. (1971) were used. The activities for the reduction reaction [acetoacetyl-CoA $+\mathrm{NAD}(\mathrm{P}) \mathrm{H} \rightarrow \mathrm{D}(-)-\beta$-hydroxybutyryl-CoA + $\left.\mathrm{NAD}(\mathrm{P})^{+}\right]$and the oxidation reaction $[\mathrm{D}(-)-\beta$-hydroxybutyryl-CoA + $\mathrm{NAD}(\mathrm{P})^{+} \rightarrow$ acetoacetyl-CoA $\left.+\mathrm{NAD}(\mathrm{P}) \mathrm{H}\right]$ were measured and calculated in the same way as for BOHB-DH.

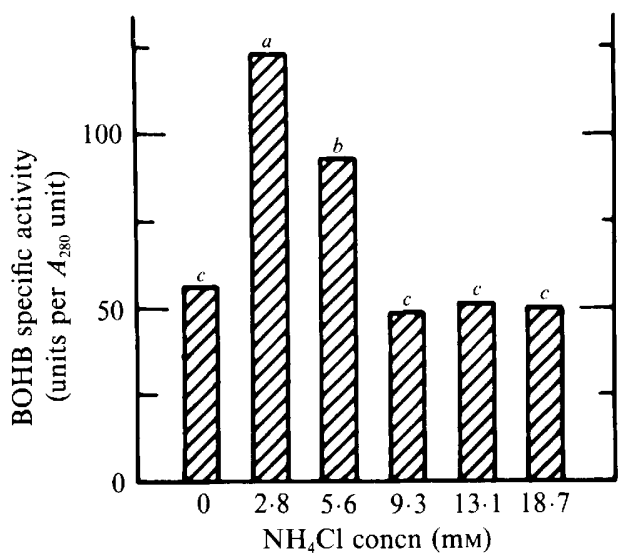

Fig. 1. BOHB-DH activity in crude extracts of $A$. brasilense cells grown for $36 \mathrm{~h}$ at different $\mathrm{NH}_{4} \mathrm{Cl}$ concentrations. Columns with the same letter are not significantly different.

For each enzyme, specific activity was defined as activity units per $A_{280}$ unit.

\section{Results}

\section{Activity of PHB cycle enzymes in crude extracts of bacteria grown with different $\mathrm{NH}_{4} \mathrm{Cl}$ concentrations}

$B O H B-D H$ activity was measured in crude extracts of bacteria grown for $36 \mathrm{~h}$ in medium containing different concentrations of $\mathrm{NH}_{4} \mathrm{Cl}$ (Fig. 1). The specific activity of the enzyme, which degrades monomers of PHB to acetoacetate, was highest in bacteria grown at the lowest $\mathrm{NH}_{4} \mathrm{Cl}$ concentration $(2.8 \mathrm{~mm})$, and thus the highest $\mathrm{C} / \mathrm{N}$ ratio (46); these cells had a high $\mathrm{PHB}$ level (around $40 \%$, w/w). At higher $\mathrm{NH}_{4} \mathrm{Cl}$ concentrations, where the cells had a lower level of PHB (up to $5 \%$ ), the BOHB-DH activity was lower. Under nitrogen-fixation conditions the activity was also low.

$\beta$-Ketothiolase. $\beta$-Ketothiolase activity was measured in crude extracts of bacteria grown for $36 \mathrm{~h}$ in medium containing two different $\mathrm{NH}_{4} \mathrm{Cl}$ concentrations (Table 1). The activity of NADH oxidase was measured prior to the addition of the substrate, disodium succinate, and served as a blank for the reaction in the condensation direction. The specific activity of $\beta$-ketothiolase in the condensation direction was higher in the (PHB-rich) bacteria grown at the lower concentration of $\mathrm{NH}_{4} \mathrm{Cl}$ than in the (PHB-poor) cells grown at the higher concentration, whereas NADH oxidase specific activity was threefold higher in crude extracts of the latter cells. In this case, there was no significant additional $\beta$ ketothiolase activity after the addition of the substrate to the crude extract. That means there is low $\beta$-ketothiolase activity in crude extracts of PHB-poor cells.

The specific activity of $\beta$-ketothiolase in the catalytic 
Table 1. $\beta$-Ketothiolase activity in the condensation and in the catalytic cleavage directions in crude extracts of $A$. brasilense cells grown with different $\mathrm{NH}_{4} \mathrm{Cl}$ concentrations

\begin{tabular}{|c|c|c|c|c|}
\hline \multirow[b]{3}{*}{ Treatment } & \multicolumn{4}{|c|}{ Specific activity (units per $A_{280}$ unit) } \\
\hline & \multicolumn{2}{|c|}{ Condensation } & \multicolumn{2}{|c|}{ Catalytic cleavage } \\
\hline & $\begin{array}{l}2.8 \mathrm{mM} \\
\mathrm{NH}_{4} \mathrm{Cl}\end{array}$ & $\begin{array}{c}14.8 \mathrm{mM} \\
\mathrm{NH}_{4} \mathrm{Cl}\end{array}$ & $\begin{array}{l}2.8 \mathrm{mM} \\
\mathrm{NH}_{4} \mathrm{Cl}\end{array}$ & $\begin{array}{c}14.8 \mathrm{mM} \\
\mathrm{NH}_{4} \mathrm{Cl}\end{array}$ \\
\hline $\begin{array}{l}\text { Preincubation } \\
\text { without the } \\
\text { substrate for } \\
3 \mathrm{~min}\end{array}$ & $39^{*}$ & $122^{*}$ & 194 & $4 \cdot 4$ \\
\hline $\begin{array}{l}\text { Incubation } \\
\text { with the } \\
\text { substrate }\end{array}$ & 90 & 129 & $0 \cdot 4$ & $4 \cdot 8$ \\
\hline Net activity & 51 & 7 & - & 0.4 \\
\hline
\end{tabular}

Table 2. Thiophorase activity in crude extracts of $A$. brasilense cells grown with different $\mathrm{NH}_{4} \mathrm{Cl}$ concentrations

\begin{tabular}{lcc}
\hline & \multicolumn{2}{c}{ Specific activity (units per $A_{280}$ unit) } \\
\cline { 2 - 3 } \multicolumn{1}{c}{ Treatment } & $2.8 \mathrm{mM}-\mathrm{NH}_{4} \mathrm{Cl}$ & $14.8 \mathrm{mM}-\mathrm{NH}_{4} \mathrm{Cl}$ \\
\hline $\begin{array}{l}\text { Preincubation } \\
\text { for 1.5 min }\end{array}$ & 3.3 & 5.7 \\
$\begin{array}{l}\text { Preincubation for } \\
\text { an additional 2 min }\end{array}$ & 3.3 & 0.1 \\
$\begin{array}{l}\text { Incubation with } \\
\text { the substrate }\end{array}$ & 8.8 & 0.2 \\
Net activity & 5.5 & 0.1 \\
\hline \hline
\end{tabular}

cleavage direction, in the same crude extracts as above, is also shown in Table 1. When the substrate was added to the crude extract of PHB-rich cells, which were grown at a low concentration of $\mathrm{NH}_{4} \mathrm{Cl}$, the activity immediately decreased from 194 to 0.4 units per $\boldsymbol{A}_{280}$ unit. This indicates that the enzyme is extremely inhibited in the presence of the substrate in crude extracts. It is possible that the activity recorded before adding the substrate is due to low internal concentrations of substrate in the crude extract. Incubation of the reaction mixture, including the substrate, for $2 \mathrm{~min}$ before the assay, led to no enzyme activity $\left(0.4\right.$ units per $A_{280}$ unit). No $\beta$ ketothiolase activity was recorded for PHB-poor cells.

Thiophorase. Thiophorase activity was measured in crude extracts of bacteria grown for $36 \mathrm{~h}$ at two $\mathrm{NH}_{4} \mathrm{Cl}$ concentrations (Table 2). During 1.5 min preincubation without the substrate, some activity was recorded for crude extracts of cells grown under both low and high $\mathrm{NH}_{4} \mathrm{Cl}$ concentrations. After $3.5 \mathrm{~min}$ of preincubation the blank activities remained constant and the substrate, disodium succinate, was added. The enzyme specific activity was much higher in crude extracts of the cells
Table 3. Acetoacetyl-CoA reductase actity in crude extracts of $\mathrm{A}$. brasilense cells grown with different $\mathrm{NH}_{4} \mathrm{Cl}$ concentrations

\begin{tabular}{lcc}
\hline & \multicolumn{2}{c}{ Specific activity (units per $A_{280}$ unit) } \\
\cline { 2 - 3 } Treatment & $2.8 \mathrm{mM}-\mathrm{NH}_{4} \mathrm{Cl}$ & $14.8 \mathrm{mM}-\mathrm{NH}_{4} \mathrm{Cl}$ \\
\hline $\begin{array}{l}\text { Preincubation } \\
\text { for 2 min }\end{array}$ & 1.5 & 2.5 \\
$\begin{array}{l}\text { Incubation with } \\
\text { the substrate }\end{array}$ & 3.8 & 3.4 \\
Net activity & 2.3 & 0.9 \\
\hline \hline
\end{tabular}

Table 4. Activity of PHB cycle enzymes in crude extracts of A. brasilense cells grown at different $\mathrm{pO}_{2}$ values

\begin{tabular}{lccc}
\hline \hline & \multicolumn{3}{c}{ Specific activity (units per $A_{280}$ unit) } \\
\cline { 2 - 4 } \multicolumn{1}{c}{ Enzyme } & $\begin{array}{c}0.024 \mathrm{mM} \\
\mathrm{O}_{2}\end{array}$ & $\begin{array}{c}0.096 \mathrm{mM} \\
\mathrm{O}_{2}\end{array}$ & $\begin{array}{c}0.024 \mathrm{mM} \\
\mathrm{O}_{2}\end{array}$ \\
\hline BOHB-DH & 52 & 14 & 13 \\
$\beta$-Ketothiolase & 41 & 39 & 11 \\
(condensation) & 7 & 4 & 3 \\
$\begin{array}{c}\text { Acetoacetyl- } \\
\text { CoA reductase }\end{array}$ & & & \\
\hline \hline
\end{tabular}

grown at the lower concentration of $\mathrm{NH}_{4} \mathrm{Cl}$, which had accumulated a high level of PHB. When the substrate was added at the beginning of the preincubation period, only half of the apparent thiophorase activities were observed.

Acetoacetyl-CoA reductase. Acetoacetyl-CoA reductase activity was measured in crude extracts of cells grown for $36 \mathrm{~h}$ at two $\mathrm{NH}_{4} \mathrm{Cl}$ concentrations. The enzyme activity during 2 min of preincubation without the substrate and NADH, after NADH addition and during incubation with the substrate is shown in Table 3 . The enzyme specific activity was higher in the cells grown at the lower $\mathrm{NH}_{4} \mathrm{Cl}$ concentration, which were rich in PHB.

Activity of enzymes of the PHB cycle in crude extracts of cells grown at different oxygen concentrations in chemostat culture

A. brasilense cells were grown in chemostat culture with malate as a growth-limiting carbon and energy source, at a moderate dilution rate $\left(D=0.14 \mathrm{~h}^{-1}\right)$, under different partial pressures of oxygen, ranging from oxygen limitation $\left(0.024 \mathrm{mM}-\mathrm{O}_{2}\right)$ to oxygen saturation in water $\left(0.24 \mathrm{~mm}-\mathrm{O}_{2}\right)$. The $\mathrm{pO}_{2}$ values were changed in the chemostat, and the cells were harvested after $24 \mathrm{~h}$ of growth at the particular $\mathrm{pO}_{2}$. Crude extracts were prepared for assay of BOHB-OH, $\beta$-ketothiolase and acetoacetyl-CoA reductase. The enzyme activities were higher in cells grown under oxygen limitation. Under 


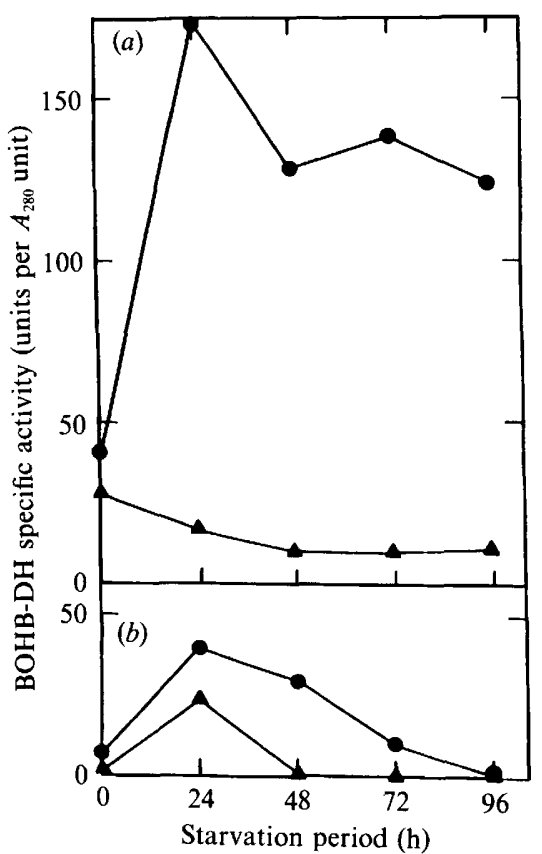

Fig. 2. BOHB-DH activity during $96 \mathrm{~h}$ of starvation in crude extracts of PHB-rich (O) and PHB-poor $(\boldsymbol{A})$ cells of $A$. brasilense. (a) Enzyme activity in the hydroxybutyrate oxidation direction; $(b)$ enzyme activity in the acetoacetate reduction direction.

oxygen saturation the enzyme activities were very low, even though the growth rate and the bacterial yield was very high relative to that under oxygen limitation (Table 4).

\section{Activity of PHB cycle enzymes in crude extracts of bacteria grown under starvation conditions}

Activity of the enzymes involved in synthesis and degradation of PHB was measured in PHB-rich and poor cells after $36 \mathrm{~h}$ of batch growth at low and high concentrations of $\mathrm{NH}_{4} \mathrm{Cl}$, respectively. These activities are considered to be the starting activities $(t=0)$ in Figs $2-5$. These bacteria were kept for an additional $96 \mathrm{~h}$ under starvation conditions and samples were taken every $24 \mathrm{~h}$ for enzyme activity assays.

$B O H B-D H$. The enzyme activity in the monomer degradation direction during starvation is shown in Fig. 2(a). The enzyme activity was high in the PHB-rich bacteria and low in the PHB-poor containing bacteria. After more than $24 \mathrm{~h}$ of starvation of PHB-rich cells, the specific activity decreased slightly, but it was still higher than that in PHB-poor cells.

The enzyme specific activity in the NADH oxidation direction (Fig. $2 b$ ) was lower than that in the reduction direction, in both PHB-rich and -poor cells.

In addition, the activity of BOHB-DH was measured in crude extracts of cells grown in medium containing different concentrations of $\mathrm{NH}_{4} \mathrm{Cl}$ and then starved for

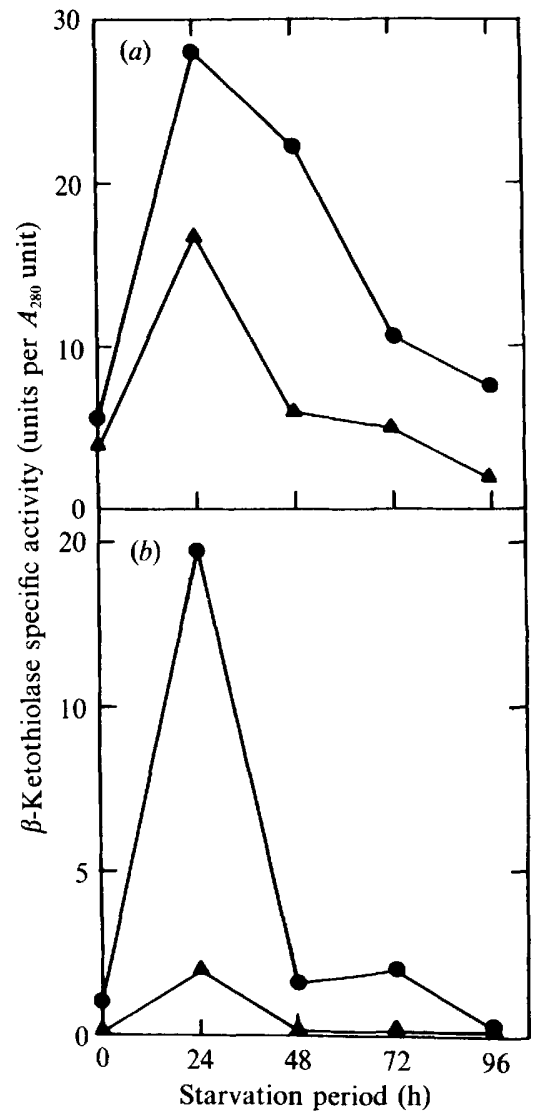

Fig. 3. $\beta$-Ketothiolase activity during $96 \mathrm{~h}$ of starvation in crude extracts of PHB-rich (O) and PHB-poor $(\boldsymbol{\Lambda})$ cells of $\boldsymbol{A}$. brasilense. (a) Enzyme activity in the condensation direction; $(b)$ enzyme activity in the catalytic cleavage direction.

$60 \mathrm{~h}$. The results were similar to those of the above experiment (data not shown).

$\beta$-Ketothiolase. $\beta$-Ketothiolase activity, in both the condensation (Fig. $3 a$ ) and the thiolysis (Fig. $3 b$ ) direction was higher in crude extracts of bacteria containing a high level of PHB than in those from PHBpoor cells. The peak of activity in both cases was after $24 \mathrm{~h}$ of starvation. In the thiolysis direction, the difference in activity between the two types of cells was much greater.

Thiophorase. Activity of this enzyme was also higher in PHB-rich than in PHB-poor bacteria. There was again a peak of activity after $24 \mathrm{~h}$ of starvation (Fig. 4).

Acetoacetyl-CoA reductase. During starvation the activity pattern of this enzyme, which participates in PHB synthesis, was different from those of the enzymes which are involved in PHB degradation (described above). The enzyme activity in the reduction was high after $36 \mathrm{~h}$ of growth and decreased to a minimum after $24 \mathrm{~h}$ of starvation. In both PHB-rich and -poor cells there was an oscillation of activity during the starvation. During the 


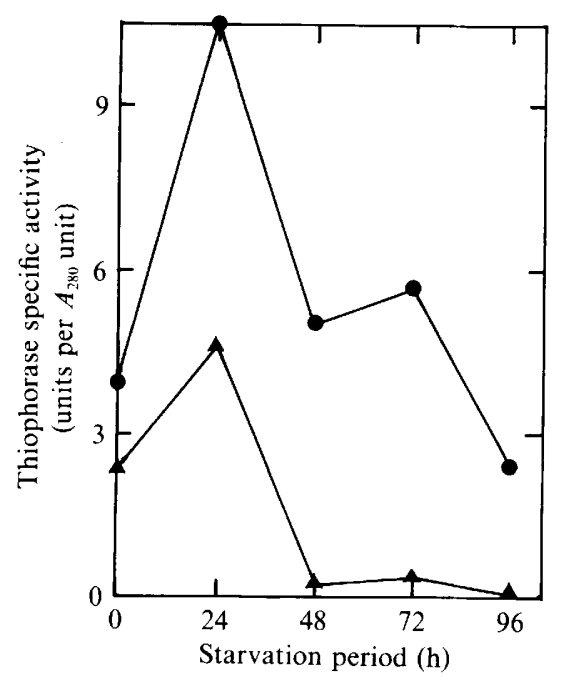

Fig. 4. Thiophorase activity during $96 \mathrm{~h}$ of starvation in crude extracts of PHB-rich ( $)$ and PHB-poor ( $\mathbf{\Lambda}$ ) cells of $A$. brasilense.

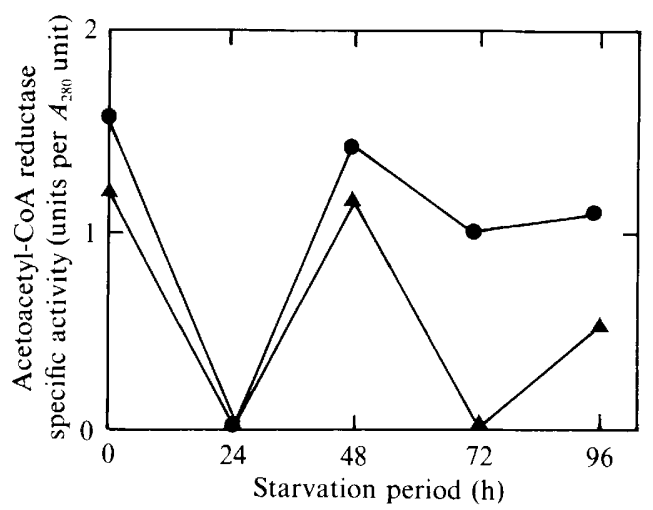

Fig. 5. Acetoacetyl-CoA reductase activity (reduction activity) during $96 \mathrm{~h}$ of starvation in crude extracts of PHB-rich (O) and PHB-poor (A) cells of $A$. brasilense.

first $48 \mathrm{~h}$ of starvation there was no significant difference between the two types of cells, but the differences became significant after 72 and $96 \mathrm{~h}$ of starvation (Fig. 5).

In the opposite direction of activity the enzyme was active only after $36 \mathrm{~h}$ of growth, and there was no activity during the starvation period (data not shown).

\section{Discussion}

In this research it was found that PHB metabolism in Azospirillum brasilense, as in Azotobacter vinelandii (Dawes \& Senior, 1973; Dawes, 1986), occurs in an cyclic pathway, in which both synthesis and degradation of the polymer, occur, depending upon the conditions. The synthesis and degradation of the polymer are under a comparable regulation which is carried out by a chain of reactions. It was shown that the polymer synthesis and degradation cycle in Azospirillum, when related to the intermediates and enzymes and to the response to oxygen limitation, is similar to the situation in Azotobacter (Senior \& Dawes, 1971, 1973; Senior et al., 1972; Jackson \& Dawes, 1976; Stockdale et al., 1986; Ward et al., 1977).

It has been shown by various authors that the resistance of micro-organisms to starvation is correlated with the PHB level in the cells and at the beginning of starvation there is a rapid utilization of the polymer (Matin, 1979; Horan \& Shanmugan, 1986; MalmcronaFriberg et al., 1986). This was also shown for Azospirillum brasilense (Tal \& Okon, 1985). During starvation, coincident with the decline in polymer level in the cells, the elliptic-circular $A$. brasilense cells become rods (Okon, 1985a). In this work the activities of the various enzymes of the PHB cycle were measured in crude extracts of bacteria approaching the end of exponential growth under oxygen- and/or nitrogen-limitation conditions, both of which favour PHB synthesis. The activities of the enzymes were also measured during $96 \mathrm{~h}$ of starvation in phosphate buffer. The loss of active synthesis and degradation enzymes, after unbalanced growth and during starvation, in both PHB-rich and -poor cells, indicates that these enzymes are probably constitutive. During PHB synthesis and accumulation the enzyme levels increased. This was shown by the higher enzyme activity achieved in PHB-rich cells, even though these bacteria had grown under unbalanced conditions and had a low growth rate, relative to PHBpoor cells. During starvation, coincident with the decline in polymer level in the cells, the total activity decreased with time. But there was a difference between the synthesis and degradation enzymes: the synthesis enzymes were not active when the degradation enzymes were active, and vice versa. The greatest changes in enzyme activities were observed after $24 \mathrm{~h}$ of starvation. The activity of acetoacetyl-CoA reductase, which participates in PHB synthesis, decreased to a minimum level after $24 \mathrm{~h}$ of starvation. Activity of the enzymes involved in PHB degradation reactions, BOHB-DH, thiophorase and $\beta$-ketothiolase, increased during the first $24 \mathrm{~h}$ of starvation. These enzymes are probably always present in the cell, but are more active under conditions in which degradation is favoured. In Rhizobium japonicum BOHB$\mathrm{DH}$ and $\beta$-ketothiolase activity increase during nitrogenase activity, and thiophorase activity decreases (Karr et al., 1984).

In $A$. brasilense the activity of the enzymes decreased following additional starvation, probably due to the release of inhibitors. Usually the decrease in enzyme activity with time occurred in an oscillatory manner; this 
is related to the polymer content in the cell (Tal \& Okon, 1985). The increase in activity which follows the decrease was presumably due to the presence of the PHB degradation products, resulting in recovery of the culture for $24 \mathrm{~h}$. After utilization of these products no more endogenous or exogenous carbon and energy sources remain. After $96 \mathrm{~h}$ there was still a low level of activity of the degradation enzymes. The synthesis enzymes were probably still present in the cell, and with improvement of the conditions, for example by adding a carbon source, the enzyme activity would be as high as it was before starvation.

This work was partially supported by a grant of the Friends of the Hebrew University of Jerusalem, Mexico.

\section{References}

DAWES, E. A. (editor) (1986). Microbial energy reserve compounds. In Microbial Energetics, pp. 145-165. Glasgow \& London: Blackie.

DAWES, E. A. \& SENIOR, P. J. (1973). The role and regulation of energy reserve polymers in micro-organisms. Advances in Microbial Physio$\log y 10,136-266$.

Horan, N. J. \& Shanmugan, P. (1986). Effect of starvation and nutrient depletion on the settling properties of activated sludge. Water Research 20, 661-666.

JACKSON, F. A. \& DAWES, E. A. (1976). Regulation of the tricarboxylic acid cycle and poly- $\beta$-hydroxybutyrate metabolism in Azotobacter beijerinckii grown under nitrogen or oxygen limitation. Journal of General Microbiology 97, 303-312.

KarR, D. B., Waters, J. K., Suzuki, F. \& Emerich, D. W. (1984). Enzymes of the poly- $\beta$-hydroxybutyrate and citric acid cycles of Rhizobium japonicum bacteroids. Plant Physiology 75, 1158-1162.

Malmcrona-Friberg, K., Tunlid, A., Marden, P., KJelleberg, S. \& ODHAM, G. (1986). Chemical changes in cell envelope and poly- $\beta$ hydroxybutyrate during short-term starvation of a marine bacterial isolate. Archives of Microbiology 144, 340-345.

Matin, A. (1979). Selective advantage of a Spirillum sp. in a carbonlimited environment. Accumulation of poly- $\beta$-hydroxybutyric acid and its role in starvation. Journal of General Microbiology 112, 349-355.

OEDING, V. \& SCHLEGEL, H. G. (1973). $\beta$-Ketothiolase from Hydrogenomonas eutropha $\mathrm{H} 16$ and its significance in the regulation of poly- $\beta$-hydroxybutyrate metabolism. Biochemical Journal 134, 239-248.

OKON, Y. (1985a). Azospirillum as a potential inoculant for agriculture. Trends in Biotechnology 3, 223-228.

Oxon, Y. $(1985 b)$. The physiology of Azospirillum in relation to its utilization as inoculum for promoting growth of plants. In Nitrogen Fixation and $\mathrm{CO}_{2}$ Metabolism, pp. 165-174. Edited by P. W. Ludden \& J. E. Burris. New York: Elsevier.

OKON, Y., Albrecht, S. L. \& BURRIS, R. H. (1976). Carbon and ammonia metabolism of Spirillum lipoferum. Journal of Bacteriology 128, 592-597.

Ritchie, G. A. F., Senior, P. J. \& Dawes, E. A. (1971). The purification and characterization of acetoacetyl-coenzyme A reductase from Azotobacter beijerinckii. Biochemical Journal 121, 309-316.

Ruhr, E. M. \& Schlegel, H. G. (1975). Synthesis of poly- $\beta$ hydroxybutyrate in vivo and kinetics of $\beta$-keto-thiolase (EC 2.3.1.16) in vitro in Alcaligenes eutrophus H-16. Biochemical Society Transactions 3, 1093-1094.

Senior, P. J. \& Dawes, E. A. (1971). Poly- $\beta$-hydroxybutyrate biosynthesis and the regulation of glucose metabolism in Azotobacter beijerinckii. Biochemical Journal 125, 55-66.

SenioR, P. J. \& Dawes, E. A. (1973). The regulation of poly- $\beta$ hydroxybutyrate metabolism in Azotobacter beijerinckii. Biochemical Journal 134, 225-238.

Senior, P. J., BeEch, G. A., Ritchie, G. A. F. \& Dawes, E. A. (1972). The role of oxygen limitation in the formation of poly- $\beta$-hydroxybutyrate during batch and continuous culture of Azotobacter beijerinckii. Biochemical Journal 128, 1193-1201.

Stockdale, H., RibBons, D. W. \& DaWes, E. A. (1986). Occurrence of poly- $\beta$-hydroxybutyrate in the Azotobacteriaceae. Journal of Bacteriology 95, 1798-1803.

TAL, S. \& OKon, Y. (1985). Production of the reserve material poly- $\beta$ hydroxybutyrate and its function in Azospirillum brasilense $\mathrm{Cd}$. Canadian Journal of Microbiology 31, 608-613.

Tal, S., Smirnoff, P. \& OKon, Y. (1990). Purification and characterization of poly- $\beta$-hydroxybutyrate in Azospirillum brasilense. Journal of General Microbiology 136, 645-649.

WARD, A. C., RowLeY, B. I. \& DAWES, E. A. (1977). Effect of oxygen and nitrogen limitation of poly- $\beta$-hydroxybutyrate biosynthesis in ammonium grown Azotobacter beijerinckii. Journal of General Microbiology 102, 61-68. 